\section{The Female and the Male Professional: Gender, Career and Expatriation Interfaces in Trajectory for Female Expatriates}

\author{
Aline Mendonça Fraga ${ }^{1}$ \\ alinemf.adm@gmail.com | (ㄷ)0000-0002-4240-464X \\ Elaine Di Diego Antunes ${ }^{1}$ \\ elaine.antunes@ufrgs.br| (1D0000-0002-0943-6041 \\ Sidinei Rocha-de-Oliveira ${ }^{1}$ \\ sroliveira@ea.ufrgs.br | (100000-0001-9139-2684
}

\begin{abstract}
While the organizational world has been experiencing the phenomenon of expatriation, the availability of mobile and international careers stand out. The differences in the expatriate experience are gendered, and few studies focus primarily on the experiences of women. This research aims to analyze the construction of the career trajectories of 19 Brazilian expatriate women, using as conceptual bases the interfaces of gender, career, and expatriation. The experiences of the participants come near to each other but compose unique trajectories, including in their personal life and professional field. The study highlights a way of being and acting in the work environment, understood as "the" model of a professional woman expatriate, who intercalates elements perceived as masculine and/or feminine. The construction of this trajectory is anchored by elements that build and influence it: personal characteristics, support and family influence, affective relationships, motherhood, professional plans and organizations in which they work, and countries of destination. With the results, possible paths are envisioned for other women seeking this experience, considering the foregrounded implications shown by this study.
\end{abstract}

\section{KEYWORDS}

expatriation, international assignment, career, gender, women
${ }^{1}$ Universidade Federal do Rio Grande do Sul, Porto Alegre, RS, Brasil 


\section{INTRODUCTION}

In Brazil, the participation of women in the labor market started to grow in the 1970s, when

the country still had an economic policy of market closure and little international interaction. In the 1990s, there was a drastic change in economic direction with the opening of the economy, the goal of which was to attract foreign products and companies, and expand the possibilities for Brazilian organizations to set up branches abroad. In this process, professional trajectories changed and diversified both nationally and internationally. Thus, with the country's entry into an economic system marked by competitiveness, the strengthening of emerging economies, and internationalization of companies, professional paths beyond national borders were marked (Freitas, 2000; Peltokorpi \& Froese, 2009).

In the Brazilian labor market, women have stood out numerically: they are the majority population (IBGE, 2016) and the majority of starting and graduating students in higher education (IBGE, 2018). Although the level of education may be a condition for higher remuneration, in the case of Brazilian women, despite their higher education, there is a salary deficit of almost $30 \%$ compared to men (IBGE, 2016). There is also a gap in political representation, promotion to managerial positions, and time devoted to the care of people and / or chores (IBGE, 2018).

In spite of the increased time devoted to work and studies, and the significant presence in entry-level jobs in organizations, such as apprentices and interns, it is noted that Brazilian women experience a hierarchical bottleneck for the highest management positions (Ethos Institute, 2016). This is an often invisible barrier that prevents women from advancing up the corporate ladder - to levels that generally means greater prestige and salary. This is known as the glass ceiling (Ezzedeen, Budworth, \& Baker, 2015) or as an indication of a labyrinth (Eagly \& Carli 2007). Thus, it can be considered that career building for women seeking to work abroad primarily faces the limited possibility of reaching a management position, given that the strategy of organizations for international careers is generally directed to such professionals (Insch, Mcintyre, \& Napier, 2008).

Research on expatriation (Baruch, Dickmann, Yochanan, \& Bournois, 2013; Van Bochove \& Engbersen, 2015; Ramaswami, Carter, \& Dreher, 2016; Polson, 2016; Gallon, Fraga, \& Antunes, 2017) highlight the growing appreciation of availability for mobility in the global organizational environment and for international careers. Expatriation is usually understood by management as the transfer of employees abroad in order to develop activities at either the foreign head office or a foreign branch office for the company in which they work, whether for a predetermined period or not. In this way, international experience is presented as a way to develop skills and achieve greater professional progression (Van Bochove \& Engbersen, 2015; Prestes, Grisci, \& Fraga, 2016). However, international careers as they relate to women's possibilities and limitations are poorly explored in Brazilian studies. Thus, this paper aims to analyze how Brazilian women build their expatriate trajectories.

Internationally, research discusses why women are deprived of expatriation over men, recognizing that gender inequality operates as a barrier to access for international experiences (Polson, 2016; Domínguez, Rivo-López, \& Villanueva-Villar , 2019; Rodriguez \& Ridgway, 2019), considered by many companies as a basic requirement for management development (Altman $\&$ Shortland, 2008; PwC, 2015). Given the lack of progress in the discussion of the topic in Brazil, there is no reference to estimate the percentage of women within the population of expatriates, whether organizational or voluntary. It is well known that, worldwide, women represent only $20 \%$ of total expatriates as workers (Brookfield Global Relocation Services, 2014). 
17

\subsection{Gender Approaches}

There are different theoretical perspectives for approaching gender, most of them related to feminist movements. Organizational studies dialogue with other areas of knowledge, such as sociology, anthropology, psychology, philosophy, history, and education, in order to discuss gender relations. In order to understand the concept, it has been considered important to bring forward the historical perspective, along with some of the feminist currents and contributions to the organizational field.

One of the first studies that sought to examine sexual identities in a comparative and crosscultural way, envisaging the social construction of ideas of male and female was published in 1935 by Margaret Mead. The anthropologist noted that women and men, at work, are forced to differentiate themselves by socially assigned roles, marking themselves by dress code, manners, and social and religious activities. These aspects can occur at the same time, or separately. Despite developing an advanced study for the 1930s, Mead's later writings were widely criticized for emphasizing motherhood as a "woman's destiny". In opposition to such a culturalist view, Simone de Beauvoir, in 1949, gained international notoriety precisely because she sought to deconstruct the "myth of motherhood" (Sardenberg, Motta, \& Gomes, 2000) and the subordinate position of women in relation to men. Economic dependence was pointed out by the author as one of the main factors that put women in a lower condition than men and which becomes expanded and legitimized through marriage, when women transfer their dependence on their father to their dependence on their husbands (Beauvoir, 1970).

Notably, from the 1970s onwards, the growth of feminist theories began to influence organizational studies. In the face of the sexual division of labor (Kergoat, 2003) and the distant situation of social, economic and political equity between men and women, feminist theorists have considerably continued to contribute to the field. A reference author in gender studies, Joan Scott (1995), states that the concept has been used in two ways: descriptive / non-causal and causal. The descriptive / non-causal form is the most simplified use of gender, understood as a synonym for women. This approach can be used to designate the social relationship between men and women, emphasizing the idea that women are raised in a male world. Apart from biological issues, it also indicates cultural construction, that is, socially created concepts have instructed the proper roles for men and women (Scott, 1995).

The causal form of gender can be approached by three feminist theoretical positions: Patriarchal, Marxist, and Psychoanalytic. In short, patriarchal theorists have sought to understand the origins of women's subordination to men's imperative to dominate them; Marxists grounded their knowledge on the basis of history, considering that the origins and transformations of gender systems are related to the sexual division of labor, so that households, families and sexualities would be the product of modes of production; and those of the psychoanalytic aspect, which, although they follow two schools with different approaches, were concerned with the processes related to the formation of the identity of the subjects, examining the development of the child and the subsequent constitution of gender identity. So, considering that gender implies sexual and social relations, Scott (1986) elaborates a concept that includes both notions: bringing power as a central construct in the understanding of gender, "gender is a constitutive element of social relationships based on perceived differences between the sexes, and gender is a primary way of signifying relationships of power." (Scott, 1986, p. 1067). 
Calás and Smircich (2006) present feminist approaches to gender by characterizing that some common assumptions can be observed, such as the recognition of the domination of man and the critical discourses of the status quo, being, therefore, of a political order. The theoretical division is slightly different from the one proposed by Scott (1995): liberal, radical, psychoanalytic, Marxist / socialist, poststructuralist / postmodern, and third worldist (postcolonialist). Considering these theories, it is important to highlight the liberal perspective, with a predominantly positivist orientation - this assumes that gender inequalities can be resolved by human development and / or legal interventions, with organizations and institutions being gender-neutral (Acker, 1990).

Such an approach is predominant in Brazilian research, revealing the ahistorical character of the female, focusing on the profile of the executive woman, as Souza, Corvino and Lopes (2013) warned. In affirming universal values, as manifested in the American liberal feminist movement, they focus primarily on the interests of white, heterosexual, and middle / upper class women. This perspective, propagated and corroborated by organizational discourse and, in many cases, by women themselves (Hryniewicz \& Vianna, 2018), does not discuss gender relations and is critically viewed by research that indicates the urgency of progress (Souza, Corvino, \& Lopes, 2013; Rodriguez \& Ridgway, 2019).

\subsection{Career and International Career}

Thirty years ago, the concept of career was already pointed as a popular theme (Arthur, Hall, \& Lawrence, 1989) and understood as central in work arrangements, especially among companies with emphasis on Human Resources Management, seeking to ensure that recruited people remained in their jobs. Considering that talking about career involves talking about socioeconomic structures, labor market characteristics, values, culture, and the historical context in which an organization was developed, the scenario changes as these configurations vary (Sullivan \& Baruch, 2009).

In this paper, trajectory is understood as a synonym for career, that is to say, "as an individual's work-related and other relevant experiences, both inside and outside of organizations, that form a unique pattern over the individual's life span" (Sullivan \& Baruch, 2009, p. 1543). Career, therefore, encompasses individual experiences, influenced by interpersonal relationships, recognizing sequential movements of positions and interpretations of people about their life trajectories as a whole.

Among career approaches seen around the turn of the twentieth century, the boundaryless career model (Arthur, 1994; Inkson, 2006) is opposed to the traditional model by pointing to a future of unlimited professional arrangements in which barriers bounded by vertical growth in an organization are no longer part of the plans. Sullivan and Arthur (2006) add to the model psychological and / or physical aspects related to competences, gender, culture, and individual differences, as conditioning factors of directions and possibilities. Due to research interest, it is noteworthy that the authors consider women more prone to psychological than physical mobility in relation to men. They are generally more influenced by family issues (husband and children) in career decision making (Sullivan \& Arthur, 2006). Complementing the "perspective of mobility", Hall (1996) proposes that careers in the 21 st century will be protean, guided by people rather than organizations, insisting on the individual and organization dichotomy. Like the Greek god Proteus, who could transform himself at will, protean careers will be reinvented from time to time at the discretion of the individual. Importantly, such career theories receive criticism for the neutral and consequently negligent view of gender and other barriers such as 
BBR

17

196

age, generation, and ethnicity (Rodrigues, Guest, \& Budjanovcanin, 2016; Tomlinson, Baird, Berg, \& Cooper, 2018).

As observed in the labor market, career models also have a gender imbalance, as they were established by male-gendered samples and generalized for women, mostly untested. The kaleidoscope career model (Mainiero \& Sullivan, 2005; Sullivan \& Mainiero, 2008) aims to address the complexities inherent to women's careers. "Like a kaleidoscope that produces changing patterns when the tube is rotated and its glass chips fall into new arrangements, women shift the pattern of their careers by rotating different aspects of their lives to arrange their roles and relationships in new ways" (Mainiero \& Sullivan, 2005, p. 111). Just as the kaleidoscope uses three mirrors, and forms unlimited color patterns, the combination of parameters such as authenticity, balance, and challenge reflect unique patterns in women's careers. Despite the advance and necessary notes on women's career flexibility to harmonize work and family (Mcdonald, 2018; Tomlinson, Baird, Berg, \& Cooper, 2018), the perspective homogenizes women's experiences.

In addition, career theories do not include expatriation in particular or explain the specificities of expatriate careers, and little research has examined how short and long-term international assignments influence career development (Sullivan, 1999). However, international career experience is considered a way to develop skills and achieve greater career progression (Prestes, Grisci, \& Fraga, 2016; Gallon, Fraga, \& Antunes, 2017).

\subsection{Expatriation and Female Expatriates}

From the perspective of this study, expatriation is "the process of transferring a professional from a company, based in one country, to work, for a determined time or not, in a unit of this company or group located in another country" (Freitas, 2000, p. 20). Given the importance of growing international business since the 1980s, research predicted that the next generation of executives would have to experience an international mission to reach the highest organizational levels (Adler, 1984). Especially after World War II, with the expansion of companies from the United States of America (USA), American managers were transferred to implement new businesses in several countries (Teixeira, Araújo, \& Machado, 2017).

There are other concepts and configurations that illustrate the different experiences abroad, especially linked to time, the type of work to be performed, and its link, or absence of it, with an organization. Examples include impatriates, patriates, flexpatriates, citizens of the world, digital nomads, international managers, transnational executives, cross-cultural managers, global executives, global managers, and self-expatriates (Gallon, Fraga, \& Antunes, 2017). Although there is a growth of studies aimed at non-traditional expatriates, considering different family backgrounds (McNulty, 2015; McNulty \& Hutchings, 2016; McNulty, Vance, \& Fisher, 2017; Guttormsen, 2018), there is also a predominance of studies that address the importance of the family as a stable bond and source of support during expatriation, taking into account the need for acculturation in the destination country (Taylor \& Napier, 2001; Lee \& Kartika, 2014). Cases of husbands accompanying wives in expatriation are very rarely portrayed in the literature and given that the spouse population is mostly female, there are stereotypes and prejudices, depending on the country to which the family is sent (Rego \& Cunha, 2009; Mäkelä, Känsälä, \& Suutari, 2011; McNulty, 2015). 
Employees and caregivers are advised to receive training and support throughout the outward and return process (Abdulla \& Jin, 2015; Guttormsen, 2018), yet it is not always possible for families to accompany the expatriate, depending on the destination country, as exemplified by Prestes, Grisci and Fraga (2016). It is worth remembering that accompanying spouses may be male or female and some of them may have chosen to temporarily give up their careers in the name of developing another's career or even to seek new opportunities (Harvey \& Wiese, 1998; Mäkelä, Känsälä \& Suutari, 2011).

Studies considering personal characteristics show that those who are sensitive, cooperative rather than competitive, better listeners, conciliatory rather than dominating, compassionate and understanding, harmonious and conflict avoidant, could perform better abroad. The 21 st century expatriate would then be a "person for all seasons" (Tung, 1995). Such stereotypical characteristics are often associated with women, so the author assumed that they could be naturally fit for international missions (Tung, 2004). However, there are indications that, unlike a caring, affective, and maternal spirit, women are forced to act in accordance with the order of managerial masculinity in view of the gendered structure of the corporate life (Acker, 1990; Connell \& Pearse, 2015).

Regarding international mobility trends, it is observed that expatriates are mostly employees who worked at the company prior to expatriation (91\%); they generally move from company headquarters or to the company's headquarters, rather than a inter-branch transfer (56\%); the prevailing age range is from 30 to 49 years old (68\%); most are male (80\%); and had no previous expatriation experience (78\%). Regarding marital status and family composition, $53 \%$ of expatriates are married men; $20 \%$ are single men; $18 \%$ are married women; and $9 \%$ are single women. Of the total, 53\% have children. Of those who are married, $78 \%$ take their families abroad (Brookfield Global Relocation Services, 2014).

Altman and Shortland (2008) indicated that the first study to address gender issues in international missions was conducted by Nancy Adler in 1979. In subsequent years, the author developed research aimed at demystifying the low participation of women in expatriations (Adler, $1984,1987,2002)$. Studies on organizational barriers imposed on women's participation in expatriations (Linehan \& Scullion, 2004; Polson, 2016; Rodriguez \& Ridgway, 2019) comparative on success and failure of expatriate men and women and gender differences in adaptation (Caligiuri \& Lazarova, 2002; Haslberger, 2010; Selmer \& Leung, 2003) are widely explored topics. The role of companies as facilitators, and even supporters in social interactions - which are critical factors for adaptation in the destination country, are part of the research concerns (Lee \& Kartika, 2014; Abdulla \& Jin, 2015).

Building a successful professional identity is a challenge for women in the international context. Caligiuri and Cascio (1998) presented four categories that affect the success of female expatriates: personal characteristics, organizations in which they work, families, and the national hosts of the place to which they are sent. Subsequently, Caligiuri, Joshi and Lazarova (1999) tested the extent to which personality, family support, company support, attitudes of national hosts, and position of authority affect the experience. From the point of view of Janssens, Cappellen and Zanoni (2006), based on successful expatriate experiences, the way they interact and position themselves as "women", "managers" and "western expatriates", paying attention to a direction that puts them closer or further from each of these roles is a particular construct that strategically places women in an advantageous position as the occasion arises. 
BBR

17

198

Given the relatively small proportion of female expatriates, the answers found in the studies are ambiguous: while trying to prove that women are successful when expatriates they show that they are usually neglected. The smaller numbers of female expatriates seem to reflect the sexual differentiation and the attributed and socially constructed gender roles, which are confirmed in the labor market and consequently in the unequal opportunities for men and women in international careers.

\section{METHODOLOGY}

A qualitative research approach was chosen (Gaskell, 2002) and a participant profile was determined, based on some main characteristics: being Brazilian; being transferred abroad to a branch or head office of the company where she worked in Brazil; in case of current expatriation, the period should be longer than three months and, if repatriated, should have remained for a period of six months or more. Data collection occurred through in-depth interviews, virtual or in person. From the interaction in the interviews, other expatriates were indicated with the snowball method or effect (Araujo, Teixeira, da Cruz, \& Malini, 2012).

The interviewees themselves were encouraged to choose pseudonyms. Some chose a name they wanted to be their own, others chose one they would name on a daughter, or in honor a woman they admired. In the characterization table (Chart 1) there is a column identifying the situation (of expatriation), whether expatriate, resident abroad, or repatriated. In total, the expatriations occurred in eleven different companies, some of which sent more than one expatriate. Areas of activity were technology, steel, automotive, oil and gas, appliances, private education, and business consulting. The age first indicated refers to the time of the interview and then there is the age at which she was expatriated.

After full transcription of the interviews, which were recorded with the permission of the interviewees, the contents were read and reread (Gaskell, 2002), in order to reach an understanding of the units of meaning that emerged from the speeches. The interviews resulted in approximately 20 hours of transcribed audio. The information of the analysis categories, emerging from the reading of the interviewees' reports, were interpreted by the content analysis technique in the light of the chosen theoretical framework.

It is noteworthy that the process of construction for the categories of analysis began with exploratory research undertaken with two expatriates - both of whom were not included in the present research. The reports collected allowed the development of a "ground zero" for the study and made it possible to glimpse possible categories of analysis, which were given a posteriori. The construction of the trajectory of female expatriates is presented as the main category and from it the elements that build it are detailed. The subcategories sometimes intersected, so they should not be considered separately. 
Chart 1

Characterization of Participants

\begin{tabular}{|c|c|c|c|c|c|c|c|}
\hline Name & Age & Graduation & $\begin{array}{l}\text { Destination } \\
\text { Country (s) }\end{array}$ & $\begin{array}{l}\text { Total } \\
\text { Expatriation } \\
\text { Time }\end{array}$ & $\begin{array}{l}\text { Marital } \\
\text { Status }\end{array}$ & Motherhood & $\begin{array}{l}\text { Expatriation } \\
\text { Situation }\end{array}$ \\
\hline Sagar & $56 / 50$ & $\begin{array}{l}\text { Foreign Trade } \\
\text { and Law }\end{array}$ & India & 4 years & Single & $\begin{array}{l}\text { Two adult } \\
\text { children } \\
\text { remained in } \\
\text { Brazil }\end{array}$ & Repatriated \\
\hline Sinara & $46 / 45$ & Administration & $\begin{array}{l}\text { China and } \\
\text { USA }\end{array}$ & 9 months & Married & $\begin{array}{l}\text { Two children } 10 \\
\text { and } 19 \text { years old } \\
\text { with her }\end{array}$ & Expatriate \\
\hline Morgana & $45 / 30$ & Maths & $\begin{array}{l}\text { Chile and } \\
\text { Japan }\end{array}$ & 2 years & Single & No & Repatriated \\
\hline Cristina & $45 / 33$ & $\begin{array}{l}\text { Administration } \\
\text { - Systems } \\
\text { Analysis }\end{array}$ & USA & 12 years & Married & $\begin{array}{l}\text { Children seven } \\
\text { and nine years } \\
\text { old, born abroad }\end{array}$ & $\begin{array}{l}\text { Resident } \\
\text { Abroad }\end{array}$ \\
\hline Alice & $42 / 42$ & $\begin{array}{l}\text { Computer } \\
\text { Science } \\
\text { and Public } \\
\text { Relations }\end{array}$ & USA & 5 months & Married & $\begin{array}{l}\text { Three-year-old } \\
\text { daughter with } \\
\text { here }\end{array}$ & Expatriate \\
\hline Laura & $39 / 37$ & $\begin{array}{l}\text { Computer } \\
\text { Science }\end{array}$ & USA & 2,2 years & Married & No & Expatriate \\
\hline Clara & $39 / 29$ & Tourism & USA & 1,7 years & Single & No & Repatriated \\
\hline Luana & $37 / 30$ & $\begin{array}{l}\text { Incomplete } \\
\text { Higher } \\
\text { Education }\end{array}$ & $\begin{array}{l}\text { USA and } \\
\text { Germany }\end{array}$ & 4,5 years & Single & No & $\begin{array}{l}\text { Resident } \\
\text { Abroad }\end{array}$ \\
\hline Belinda & $35 / 38$ & $\begin{array}{l}\text { Incomplete } \\
\text { Higher } \\
\text { Education }\end{array}$ & Mexico & 3 years & Married & $\begin{array}{l}\text { Pregnancy } \\
\text { abroad }\end{array}$ & Repatriated \\
\hline Giane & $34 / 30$ & $\begin{array}{l}\text { Production } \\
\text { Engineering }\end{array}$ & China & 3,5 years & Single & No & Expatriate \\
\hline Cássia & $34 / 29$ & Administration & USA & 5 years & Married & $\begin{array}{l}\text { Three-year-old } \\
\text { son born abroad }\end{array}$ & Expatriate \\
\hline Cláudia & $34 / 25$ & Psychology & Canada & 1,2 years & Single & No & Repatriated \\
\hline Raquel & $33 / 29$ & $\begin{array}{l}\text { Advertising } \\
\text { and Marketing }\end{array}$ & USA & 3 years & Married & $\begin{array}{l}\text { Pregnancy } \\
\text { abroad }\end{array}$ & Repatriated \\
\hline Camile & $33 / 27$ & Psychology & USA & 2 years & Single & No & Repatriated \\
\hline Fabiana & $31 / 27$ & $\begin{array}{l}\text { Metallurgical } \\
\text { Engineering }\end{array}$ & Singapore & 11 months & Single & No & $\begin{array}{l}\text { Resident } \\
\text { Abroad }\end{array}$ \\
\hline Jéssica & $30 / 29$ & Administration & USA & 1,5 years & Married & No & Expatriate \\
\hline Rúbia & $29 / 24$ & $\begin{array}{l}\text { Chemical } \\
\text { Engineering }\end{array}$ & $\begin{array}{l}\text { Kuwait e } \\
\text { USA }\end{array}$ & 5 years & Single & No & Expatriate \\
\hline Amanda & $29 / 29$ & Administration & England & 7 months & Single & No & Expatriate \\
\hline Antonella & $29 / 24$ & $\begin{array}{l}\text { Materials } \\
\text { Engineering }\end{array}$ & Chile & 6 months & Single & No & Repatriated \\
\hline
\end{tabular}




\title{
4. ANALYSIS OF RESULTS
}

Although they are often close to each other, the experiences of the research participants make up unique trajectories, including in personal and professional fields. In order to carry out a joint analysis of the cases, space was opened to identify these points. It starts with the professional construction of a female expatriate, which intersperses the valorization of attributes considered masculine and / or feminine, followed by elements that build and influence this trajectory: personal characteristics, family support and influence, affective relationships and motherhood, professional plans, and the organizations in which they work and countries of destination.

\section{1. “The” Professional Female Expatriate ${ }^{1}$}

In view of the elements highlighted as fundamental for building the trajectories of the female expatriate surveyed, it was observed that "acting as a man", as mentioned by Antonella - "sometimes you have to act as a man would act. And women acting like men are thick, men are normal” "working as equals" and behaving like "a professional" were present in several interview reports. At many times they used the male article to refer to themselves at work, such as Sagar: "I took the advice of a Commercial Director, and he would say to me, 'You are not a woman, you are a professional. A professional has no sex while he's acting professionally.' The speech corroborates what Alice said:

\footnotetext{
If you are a woman, and you are shy and you do not talk during a meeting, you will have more difficulty to make your point, to show your work, or that you are capable of leading, finally, showing you as a potential professional, but if you are a woman who arrives in a meeting and speaks to others as equals, you will move on.
}

And this is exaggerated in Morgana's report, which reflects the potentializing of aspects considered as masculine to produce power spaces (Acker, 1990; Scott, 1995) in the organizational environment.

\begin{abstract}
I just wasn't a man because I didn't have the genitals. Because all my professional behavior was male. So my professional constitution was in the male gender, not the female gender. And because my efforts gave results. So there was the thing of giving results and the thing that I was more macho than a lot of people inside that company. I mean many people. This I tell you, neither with pride, nor with shame because I can look at the past, so today I can analyze it with ease. But, I went through that moment that if I had an employee who had a performance problem, my scheme was to sit together in a room and talk until the person cried. When the person starts crying you leave, right? So, this sadistic thing, the sadistic manager, the imposition of power (Morgana).
\end{abstract}

It was noticed that this is an alternative form of behavior that aims to minimize differences in the work environment, reducing aspects considered fragile in women or bad in the eyes of men. That is, the ideal posture is the one which draws attention to the aspect that matters to the company - the work - and will be essential for the invitation by the company or for the search for a job abroad. Within a logic of building boundaryless careers (Arthur, 1994; Inkson, 2006), it is noted that professional conduct is limited by gender transposition, with the adoption of a posture associated with male stereotype in organizations, especially aggressive conduct and strong positioning.

However, for women expatriates, the advantages of being a woman should be harnessed with restrictions, so as not to lose professional respect: "If you are in an environment with many men, 
if you know how to use the power of being a woman, you get a lot. I do not say in this thing of being sensual, in these things, but in the professional sense" (Fabiana). "I think women in a typically male environment have a big advantage, we get things easier and faster, and we don't have to use sexuality, it's just being professional with a feminine way" (Giane).

As seen in the early feminist theories, essentially liberal and psychoanalytic, the arguments seemed to be centered on the questions of 'equality', 'similarity' or 'differences' in order to make both sexes and their sexualities occupy the same place in society without oppression or subordination (Calás \& Smircich, 2006; Domínguez, Rivo-López, \& Villanueva-Villar, 2019). Other women expatriates demonstrated the empowerment of the male as dominant (Acker, 1990; Connell \& Pearse, 2015), both abroad and in Brazil, and the imperative of a strong, imposing posture, a performance at work as active agents in their relationships with local or foreign men (Janssens, Cappellen, \& Zanoni, 2006).

To the extent that the presence of women is insignificant in international assignments, professional opportunities are sometimes stagnant. With the advent of international experience as highly required for global leaders, women's inability to achieve an expatriation experience proves to be a concrete impediment to hierarchical advancement in most global corporations

\subsubsection{Personal characteristics, support and influence of the family}

All interviewees, directly or indirectly, had a period of preparation for expatriation during their trajectory. Some, recalling childhood, reflected on the enchantment with professions related to mobility: "Every child wants to be a teacher, every woman at some point when she is a child, wants to be a secretary, a flight attendant. I remember that a lot. I wanted to be a flight attendant, secretary, I wanted to be a diplomat and I did a little of all this" (Sinara); "I fed the dream of being a journalist, actress, singer, flight attendant" (Sagar); "Since I can remember I wanted to be many things, I wanted to be a teacher, I wanted to be a flight attendant, I think that childish thing, that goes on seeing the papers, goes on fantasizing" (Cláudia).

What was learned from the family appeared to encourage study and career choices in the future. This understanding is in line with research that considers career as inserted in the universe in which people and their work are established, being essential to understanding the influences received from the family, society, and the cultural context in which one grew up (Sullivan \& Baruch, 2009; Polson, 2016; Rodriguez \& Ridgway, 2019). The focus of the influence was on the figure of their mothers, by encouraging them to study, work and not depend on anyone financially.

That was my mother's catechesis, right? Three female daughters. The catechesis was: never depend on men. None of the three depends on men. That is, catechesis had an effect, you know? [...] Basic catechesis every day was: you don't have to do anything other than study. My mother was very complicated, she did not want us to do any chores, so as not to fall into the routine that women do housework and men, like, go to work and have a profession. Our service was to study. That was it and period (Morgana).

One thing I always knew was that I wanted to study, because the one thing I always hated was helping my mom do housework. I never wanted to learn to cook, never wanted to do anything, and I always told my mom that I was going to study and work even if it was just to pay a maid. I always dedicated a lot of myself to studies (Laura).

Sagar, who among the interviewees is the oldest one, made a characteristic comment of her generation, since women were long raised to be wives (Beauvoir, 1970; Sardenberg, Motta, \& 
Gomes, 2000). This included being economically dependent on her husband (Beauvoir, 1970; Rodriguez \& Ridgway, 2019) and solely responsible for household chores, which prevented or limited her studies and professional practice. "The young women who could go a little beyond were bankers, teachers, public servants, etc. The truth is that we were raised and prepared for marriage. The woman had to get married, start a family, have children, and live happily ever after" (Sagar).

It is noteworthy that, from the 19 participants, seven had an exchange abroad, work and / or study, prior to the expatriation experience, in order to learn or expand the knowledge of languages, especially English. The language was mentioned in almost every interview as an advantage for those who have started studying since childhood or adolescence. Having lived in different places seemed a facilitator, both for expatriates and for companies when recruiting and selecting. Flexibility and the ability to build and deconstruct herself and her bonds (Freitas, 2000, González \& Oliveira, 2011) appeared as key to the experience of expatriation, as the mobility potential for the company is highlighted, pointing to the tendency of agility to adapt to new work environments and cultural realities.

\subsubsection{Affective Relationships and Motherhood}

Regarding the participants affective relationships, eight out of 19 were already married when expatriates and all husbands accompanied them abroad. Alice and Belinda work for the same company as their husbands and the couples were expatriates together. In such cases, as well as Cristina's, in which her husband accompanied her as an expatriate from another company, it was noted that the fact that the spouse does not have to renounce on his career facilitates the experience abroad, and gives greater emotional and financial stability for the couple.

Camile, in addition to being an expatriate, works in the area of Human Resources with expatriate management. She commented that experiences of dual career couples (Harvey \& Wiese, 1998; Mäkelä, Känsälä, \& Suutari, 2011; McNulty, 2015; Guttormsen, 2018) are already recognized as a critical point in inviting or accepting an expatriate candidate, given that someone ends up "giving up her/his job, her/his life". She emphasizes that the social pressure falls on the man who gives up work to accompany the woman, since they often cannot relocate abroad or do not put themselves in well-paid jobs.

This situation was experienced by all husbands who accompanied their wives without being also expatriates. Although planned and supported, at some point there were situations of discomfort with the absence of work: "he kind of started to get depressed here, and I think, when it's a woman, the pressure is even higher, there's the fact that I'm working, he is staying at home, several cultural things that we carry in our luggage"(Cassia); "The woman comes along, gets a poor job, or doesn't even work, they make a deal that she's going to take care of her son, okay, and it's not like that for the man. The man has that thing of not being able to stay at home" (Jessica); "Wives went there a lot to be expatriate wives, very few actually went to work, and my husband didn't want that, of course not, and I didn't want him to become an expatriate husband" (Raquel).

It was noted that although they demonstrate not to care about stereotypes or roles understood as of "men" and "women", there was some prejudice in the speeches, in many cases, recognized by the participants, showing that gender is an element that constitutes social relationships from perceived differences (Scott, 1995). In Raquel's speech, the fact that the man is in a situation that is common to women seems to devalue him socially: "I think this was the biggest difficulty, we even joked about it, made it a joke: what if you go out with the girls to shop? Go occupy yourself 
with the girls!" Cassia corroborates that the discomfort affects both: "You end up meeting Brazilian families who are here, in similar situations and, for the most part, it is the man who came [for international assignment]. So there is even this presentation question, it is strange, understand? You go through situations where sometimes you even suffer prejudice." The speeches represent a culturally constructed pattern of thinking that goes back to the beginning of feminist studies: it is unknown where exactly the definition of woman as 'the other' comes from (Beauvoir, 1970), but men and women differ socially and attribute themselves roles that disturb them when they are not fulfilled. Even with women's professional advancements, the sexual division of labor and the expectation that men will be the provider follow open-ended questions that need to be problematized (Kergoat, 2003; Connell \& Pearse, 2015).

Regarding the importance of family support, especially of the spouse, in the context of expatriation, a topic widely discussed in the literature on the subject (Freitas, 2000; Taylor \& Napier; 2001; Lee \& Kartika, 2014), there was harmony between reports, either in the decision to accept the invitation or to apply for an international opportunity, such as while in the country of destination.

Marriage was not directly related to having children, as some reported that they do not have this desire and do not associate it with investing in their careers: "We have no children and we have no plans to have and this is not career related, it does not match our lifestyle" (Laura); "I make no plans to have children. I even talked to my husband and, in his family, one gets married to have children, they are catholic, very traditional. But I've already made it clear that I don't have these plans" (Luana). In the cases of those who had children or became pregnant during the period abroad, the following factors were taken into account, such as quality of life in the destination country, benefits from labor legislation, losses due to the lack of family members, the possibility of having or not having babysitting, among others balanced in consensus between the couples. Therefore, it is important to think about the diversity of family characteristics of women in management positions - commonly portrayed as single, divorced and, if married, without children (Linehan \& Scullion, 2004; Polson, 2016).

\subsubsection{The professional plans and the organizations in which they work}

Expatriation has been illustrated in the speeches as an advantageous opportunity to change, to open up to the new: "if you are a person who wants to develop and grow as a person and professional, you will like to change" (Giane); "A lot of personal development. It is a breaking of paradigms [...] we have such an experience, no day is the same as another, however hard it is, we learn a lot from it" (Sinara). They also express the growth expectations that experiencing expatriation produces: "I thought it would greatly value my career [...] I knew the market would value me much more if I went back to Brazil with an international experience, that would open many doors for me" (Raquel).

Having a career path and clear career goals was considered a differential for the female expatriates (Sullivan \& Arthur, 2006; Domínguez, Rivo-López, \& Villanueva-Villar, 2019). Therefore, it is essential to indicate to the company the objective, in addition to the necessary technical skills and communication skills in the language of the destination country, characteristics considered essential for any expatriate candidate. In the case of women, the myth that they "don't want" to go abroad still prevails in organizational discourse, so it is necessary to highlight the intention and potential for mobility. 
BBR

17

204

Some of the participants work in areas where men have historically predominated, such as in the exact sciences, engineering and information technology or, even when they are the majority, as in psychology, they realize that there is a limitation in professional advancement (Calás \& Smircich, 2006; The Global Gender Gap Report, 2014). The perception of the extraordinarily competent woman figure (Adler, 1987), which is still generally neglected in relation to a male colleague, is reflected in the lines. Cláudia's report elaborates on the glass ceiling barrier (Insch, Mcintyre \& Napier, 2008; Domínguez, Rivo-López, \& Villanueva-Villar, 2019), approximating the idea of a labyrinth (Eagly \& Carli, 2007) that prevents women from reaching managerial positions and, consequently, expatriation.

There is a funnel and it is a gender funnel. Just it. I've seen a lot of times when, especially in the HR area, which has a lot of women, you had the man and the woman and only one position, and the two are on the same level or the woman was strongest, and who got the job was the man (Cláudia).

Sometimes, the same expatriate woman pointed out the difficulties of working in a maledominated environment, which made her feel displaced, and then, at another point commented that being a woman represented something that made things easier, demonstrating that the situation can be seen from different points of view (Polson, 2016; Rodriguez \& Ridgway, 2019). The easy things seem to be related to behaving like "a female professional" because, to the extent that one finds the right way to act enhancing the positive aspects of the female, there will be advantages (Tung, 2004).

\subsubsection{The Destination Country}

Several reports considered that being Brazilian woman was a negative factor, mainly based on the stereotype linked to Brazilian women' sensuality and the trickiness of Brazilians: "when I met my husband and some friends of his, there were some who said: 'Oh, it's Brazilian'. And they looked that way up and down" (Luana); "Our fame is not good, this Brazilian way, party, carnival, soccer, is not a good image they have of Brazilian professionals, you have to build your reputation" (Giane).

The interviewees mentioned situations of discrimination, either because they were women, because they were Brazilian or both, especially in work areas where women are still a minority. This is the case of Antonella, materials engineer. As soon as she arrived at her place of work, she heard from a manager: "What is this Barbie [doll] doing here? Why did you send me this Barbie?" And commented on other cases of colleagues who were not accepted by the national hosts. Sexual harassment cases have also been mentioned, both in countries where women are restricted in their freedom of labor, such as Kuwait - Rúbia's destination - or in a country with considerable gender equality, such as the United States, Luana's first expatriation destination.

The destination country, therefore, can influence the expatriate women's perception and, in different ways, affect the way she lives out the experience. In accordance with the work of Rodriguez and Ridgway (2019), expatriate women live and work in a constant dynamic of privilege and disadvantage, so they cannot be considered as a privileged elite, even though professional mobility is indicative of social and economic advancement (Domínguez, Rivo-Lopez, \& Villanueva-Villar, 2019). In any case, it was observed that even in countries where there are few women in well-paid jobs, especially in management positions, such as India, Singapore, and Kuwait, female expatriates in general were seen as "foreigners that were women". At some point, such a condition, also benefiting from the position of power, may have facilitated their insertion 
in the workplace, even with several obstacles because they are women in male-marked countries and organizational structures (Polson, 2016; Connell \& Pearse, 2015).

\section{FINAL DISCUSSION}

In this research, it is recognized that the categories considered as fundamental to the "success of female expatriations" are in fact relevant: personal characteristics, companies, families, as well as factors that improves adaptation in the experience of expatriation; for instance personality, family support, company support, attitudes of national hosts, and position of authority. However, it was observed that these elements, from the female expatriate's perspective, are not sufficiently capable of defining success or failure, nor determining the (im)possibility of reaching an expatriation opportunity. Linked to the notion of career, expatriation is understood as an experience that provides mainly personal growth.

Being an expatriate for the research participants is an experience that is made possible, first of all, by personal will, whether it was aroused by a childhood fantasy or by the area of activity, allied to family support, in the form of encouraging study of languages and socialization with other cultures, or the spouse, in the case of married women, that stimulates the career of the wife, and is willing to possibly give up his career in Brazil. Secondly, by the companies they work for, which have opportunities abroad and, if possible, are open enough to consider the expatriation of women, as some of the interviewees mentioned that they were pioneers in expatriation, and only because of them were the doors were opened for the others.

It is noteworthy that the construction of a trajectory is anchored in the figure of "a professional". The composition of a professional, safeguarding the personal specificities and characteristics of the area of training, is formed by an understanding to behave based on the idea of "being a man", combined with aspects of "being a woman" as the moment requires. The (fe)male "professional" should find the right way to position herself, so being a woman can be an advantage, although loaded with stereotypes and disadvantages, as pointed out in the literature. The adoption of the male posture often implies adopting a behavior marked by aggressiveness and toughness to ensure respect and space.

As a synthesis of the other elements that build and influence the trajectories of the participants, the results shown:

a) Personal characteristics related to family support: it is easier when, in the family environment, there are no prejudices and gender roles or there is room for discussion of alternative ways. Thus, it made it possible to choose professions according to their own interests and finding themselves capable of having an independent financial life. The incentive to work and study was very evident in the reference to their mothers.

b) How they balance their affective relationships and motherhood: Marriage and motherhood are not impediments when seeking an expatriation experience. At this point, different cases and possibilities of configurations were found, considering that: there are women who prioritize professional choices when single and without children; others who found in their partners the support to leverage their careers; there are married women who do not intend to have children; others who had children and started to list priorities in other ways, thus, it became a priority to be closer to families, returning to Brazil, or being in a country with a perceived better quality of life, preferring to stay abroad. 
BBR

17

206

c) Professional plans and the possibility of carrying them out in the organizations in which they work: having a career plan, setting goals, and actually being prepared for an expatriation experience is crucial. However, whether in Brazil or in the destination country, one must be willing to face obstacles and prejudices not only for being a woman, but also: for being young; for enduring in a predominantly male field; for not finding other women to exchange ideas and experiences with; and for the absence of gender policies that encourage and facilitate the career advancement of women.

d) Countries of expatriation destination: may be a limiting factor because some countries do not accept transfers of women to subsidiaries abroad. Even in less extreme situations, the experience may require efforts by the expatriate to overcome situations of discrimination. Brazilian woman especially must be prepared for a stereotype that affects all people who leave the country and go abroad, but is aggravated in females, making them sometimes targets of sexual harassment.

Importantly, although some of the women expatriates mentioned their lower-class background and non-white descent, we spoke, in this research, about the experiences of mostly white, heterosexual women, who work in large companies and had family financial support. Thus, undeserving the personal and professional efforts to achieve their professional advancement, this is a privileged group, as highlighted by Rodriguez and Ridgway (2019), who was able to make choices and invest in their aspirations.

While there is harmony in points of the trajectories and situations experienced in the context of expatriation, there were differences of opinion about the experience in the same destination country or about the perception of equality or inequality of career opportunities for women in relation to men. In these situations, there were times when the personal sphere weighed more and, in others, the professional, as a kaleidoscope (Sullivan \& Mainiero, 2008), following the perspective that understands the career as a whole, beyond organizational boundaries. Specifically, in the understanding of women as professionals, there is a generational relationship in the way of viewing the imbalance of the labor market, since all interviewees over 45 years of age experienced situations of discrimination, regardless of company branch. Gaps in opportunities related to being women, and the narrowing of careers to managerial positions, created situations that precede the low presence of expatriate women, which were highlighted by the participants.

Regarding the limitations, what has been anticipated by international research stands out: due to the low proportion of female expatriates, the research presents ambiguities and then falls on the myths addressed for more than 30 years by Nancy Adler, forcing comparisons between male and female expatriations and trying to prove that they are more or equally successful. As a research agenda, it is suggested to broaden the discussion on nontraditional expatriates (Guttormsen, 2018), including women's mobility limitations, which even white and middle / upper class women experience career disadvantages in the face of a global male elite. Both nationally and internationally, there are gaps to discuss critical points in gender research that have the potential to contribute to career and mobility studies, such as intersectionality and influences of other social markers of difference, such as class, sexuality, race / color, ethnicity, disability and nationality. 


\section{REFERENCES}

Abdullah, D. N. A. A., \& Jin, C. S. (2015). Determining the types of training and development supports for expatriates. Procedia - Social and Behavioral Sciences, 172, 548-554.

Acker, J. (1990). Hierarchies, jobs, bodies: A theory of gendered organizations. Gender \& Society, $4(2), 139-158$.

Adler, N. J. (1984). Women do not want international careers: And other myths about international management. Organizational Dynamics, 13(2), 66-79.

Adler, N. J. (1987). Pacific basin managers: A gaijin, not a woman. Human Resource Management, 26(2), 169-191.

Adler, N. J. (2002). Global managers: No longer men alone. International Journal of Human Resource Management, 13(5), 743-760.

Altman, Y., \& Shortland, S. (2008). Women and international assignments: Taking stock - a 25-year review. Human resource management: Published in cooperation with the School of Business Administration, The University of Michigan and in alliance with the Society of Human Resources Management, 47(2), 199-216.

Araujo, B. F. V. B., Teixeira, M. L. M., da Cruz, P. B., \& Malini, E. (2012). Adaptação de expatriados organizacionais e voluntários: Similaridades e diferenças no contexto brasileiro. Revista de Administração, 47(4), 555-570.

Arthur, M. B. (1994). The boundaryless career: A new perspective for organizational inquiry. Journal of Organizational Behavior, 15(4), 295-306.

Arthur, M. B., Hall, D. T., \& Lawrence, B. S. (Eds.). (1989). Handbook of career theory. Cambridge: Cambridge University Press.

Baruch, Y., Dickmann, M., Altman, Y., \& Bournois, F. (2013). Exploring international work: Types and dimensions of global careers. The International Journal of Human Resource Management, 24(12), 2369-2393.

Beauvoir, S. D. (1970). O segundo sexo (vol. 1: Fatos e mitos). Sérgio Milliet, Trans. São Paulo: Nova Fronteira.

Brookfield Global Relocation Services (2014). Global Relocation Trends Survey. Estados Unidos, 2014. Retrieved from http://www.brookfieldgrs.com/wp/wp-content/uploads/toolbox.v.2/ GMTS_2014-GMTS.pdf/

Calás, M., \& Smircich, L. (2006). From the woman's point of view ten years later: Towards a feminist organisation studies. In S. R. Clegg, C. Hardy \& T. B. Lawrence, The SAGE handbook of organization studies (pp. 284-346). London: SAGE Publications.

Caligiuri, P. M., \& Cascio, W. F. (1998). Can we send her there? Maximizing the success of western women on global assignments. Journal of World Business, 33(4), 394-416.

Caligiuri, P. M., Joshi, A., \& Lazarova, M. (1999). Factors influencing the adjustment of women on global assignments. International Journal of Human Resource Management, 10(2), 163-179.

Caligiuri, P., \& Lazarova, M. (2002). A model for the influence of social interaction and social support on female expatriates' cross-cultural adjustment. International Journal of Human Resource Management, 13(5), 761-772.

Connel, R., \& Pearse, R. (2015). Gênero: uma perspectiva global. São Paulo: nVersos.

Domínguez, M. B., Rivo-López, E., \& Villanueva-Villar, M. (2019). 'The glass ceiling': Myth or reality? An expatriation perspective. Organizational Dynamics, 2019 (Article in press). 
BBR

17

208

Eagly, A. H., \& Carli, L. L. (2007). Through the labyrinth: The truth about how women become leaders. Boston: Harvard Business Press.

Ezzedeen, S. R., Budworth, M. H., \& Baker, S. D. (2015). The glass ceiling and executive careers: Still an issue for pre-career women. Journal of Career Development, 42(5), 355-369.

Freitas, M. E. de (2000). Como vivem os executivos expatriados e suas famílias? Relatório de Pesquisa (n. 7, pp. 1-117). EAESP/FGV/NPP, Núcleo de Pesquisas e Publicaçôes.

Gallon, S., Fraga, A. M., \& Antunes, E. D. D. (2017). Conceitos e configuraçóes de expatriados na internacionalização empresarial. REAd-Revista Eletrônica de Administração, 23, 29-59.

Gaskell, G. (2002). Entrevistas individuais e grupais. In M. W. Bauer, \& G. Gaskell, Pesquisa qualitativa com texto, imagem e som: Um manual prático (v. 2, pp. 64-89). Petrópolis: Vozes.

González, J. M. R., \& de Oliveira, J. A. (2011). Os efeitos da expatriação sobre a identidade: Estudo de caso. Cadernos EBAPE.BR, 9(4), 1122-1135.

Guttormsen, D. S. (2018). Does the 'non-traditional expatriate' exist? A critical exploration of new expatriation categories. Scandinavian Journal of Management, 34, 233-244.

Hall, D. T. (1996). Protean careers of the 21st century. Academy of Management Perspectives, 10(4), 8-16.

Harvey, M., \& Wiese, D. (1998). The dual-career couple: female expatriates and male trailing spouses. Thunderbird International Business Review, 40(4), 359-388.

Haslberger, A. (2010). Gender differences in expatriate adjustment. European Journal of International Management, 4(1/2), 163-183.

Hryniewicz, L. G. C., \& Vianna, M. A. (2018). Mulheres em posição de liderança: Obstáculos e expectativas de gênero em cargos gerenciais. Cadernos EBAPE.BR, 16(3), 331-344.

Inkson, K. (2006). Protean and boundaryless careers as metaphors. Journal of Vocational Behavior, 69(1), 48-63.

Insch, G. S., McIntyre, N., \& Napier, N. K. (2008). The expatriate glass ceiling: The second layer of glass. Journal of Business Ethics, 83(1), 19-28.

Instituto Brasileiro de Geografia e Estatística (IBGE). (2018). Estatísticas de gênero: Indicadores sociais das mulheres no Brasil. Retrieved from https://biblioteca.ibge.gov.br/visualizacao/livros/ liv101551_informativo.pdf

Instituto Brasileiro de Geografia e Estatística (IBGE). (2016). Sintese dos indicadores sociais: Uma análise das condiçóes de vida da populaçâo brasileira. Retrieved from https://biblioteca.ibge.gov. $\mathrm{br} /$ visualizacao/livros/liv98965.pdf

Instituto Ethos de Empresas e Responsabilidade Social. (2016). Perfil social, racial e de gênero das 500 maiores empresas do Brasil e suas açóes afirmativas. Retrieved from http://www.onumulheres. org.br/wp-content/uploads/2016/04/Perfil_social_racial_genero_500empresas.pdf

Janssens, M., Cappellen, T., \& Zanoni, P. (2006). Successful female expatriates as agents: Positioning oneself through gender, hierarchy, and culture. Journal of World Business, 41(2), 133-148.

Inkson, K. (2006). Protean and boundaryless careers as metaphors. Journal of Vocational Behavior, 69(1), 48-63.

Kergoat, D. (2003). Divisão sexual do trabalho e relações sociais de sexo (pp. 55-63). Trabalho e cidadania ativa para as mulheres: Desafios para as Politicas Públicas. São Paulo: Coordenadoria Especial da Mulher. 
Lee, L. Y., \& Kartika, N. (2014). The influence of individual, family, and social capital factors on expatriate adjustment and performance: The moderating effect of psychology contract and organizational support. Expert Systems with Applications, 41(11), 5483-5494.

Linehan, M., \& Scullion, H. (2004). Towards an understanding of the female expatriate experience in Europe. Human Resource Management Review, 14(4), 433-448.

Mainiero, L. A., \& Sullivan, S. E. (2005). Kaleidoscope careers: An alternate explanation for the “opt-out” revolution. Academy of Management Perspectives, 19(1), 106-123.

Mäkelä, L., Känsälä, M., \& Suutari, V. (2011). The roles of expatriates' spouses among dual career couples. Cross Cultural Management: An International Journal, 18(2), 185-197.

McDonald, P. K. (2018). How 'flexible' are careers in the anticipated life course of young people? Human Relations, 71(1), 23-46.

McNulty, Y. (2015). Acculturating non-traditional expatriates: A case study of single parent, overseas adoption, split family, and lesbian assignees. International Journal of Intercultural Relations, 49, 278-293.

McNulty, Y., \& Hutchings, K. (2016). "Looking for global talent in all the right places: A critical literature review of non-traditional expatriates". The International Journal of Human Resource Management, 27(7), 699-728.

McNulty, Y., Vance, C. M., \& Fisher, K. (2017). Beyond corporate expatriation - Global mobility in the sports, religious, education and non-profit sectors. Journal of Global Mobility: The Home of Expatriate Management Research, 5(2), 110-122.

Peltokorpi, V., \& Jintae Froese, F. (2009). Organizational expatriates and self-initiated expatriates: Who adjusts better to work and life in Japan? The International Journal of Human Resource Management, 20(5), 1096-1112.

Polson, E. (2016). Negotiating independent mobility: Single female expats in Bangalore. European Journal of Cultural Studies, 19(5), 450-464.

Prestes, V. A., Grisci, C. L. I., \& Fraga, A. M. (2016). Estilos de vida de trabalhadores em contexto de expatriação. Revista de Administração Mackenzie (Mackenzie Management Review), 17(3), $39-59$.

PwC. (2015, March). Developing female leaders: Addressing gender bias in global mobility. Australia, 2015. Retrieved from http://www.pwc.com/gx/en/women-at-pwc/internationalwomensday/ next-gen-diversity-publication.jhtml

Ramaswami, A., Carter, N. M., \& Dreher, G. F. (2016). Expatriation and career success: A human capital perspective. Human relations, 69(10), 1959-1987.

Rego, A., \& Cunha, M. P. (2009). Manual de gestão transcultural de recursos humanos. Lisboa: Editora RH.

Rodrigues, R., Guest, D., \& Budjanovcanin, A. (2016). Bounded or boundaryless? An empirical investigation of career boundaries and boundary crossing. Work, Employment and Society, 30(4), 669-686.

Rodriguez, J. K., \& Ridgway, M. (2019). Contextualizing privilege and disadvantage: Lessons from women expatriates in the Middle East. Organization, 26(3), 391-409.

Sardenberg, C. M. B., Motta, A. B. D., \& Gomes, M. (2000). Um diálogo com Simone de Beauvoir e outras falas. Núcleo de Estudos Interdisciplinares sobre a Mulher. Salvador: NEIM, FFCH/ UFBA, 2000. 
BBR

17

Scott, J. (1995). Gênero: uma categoria útil de análise histórica. Educação \& Realidade, 20(2), 71-99.

Selmer, J., \& Leung, A. S. (2003). Personal characteristics of female vs. male business expatriates. International Journal of Cross Cultural Management, 3(2), 195-212.

Souza, E. M. D., Corvino, M. D. M. F., \& Lopes, B. C. (2013). Uma análise dos estudos sobre o feminino e as mulheres na área de administração: A produção científica brasileira entre 2000 a 2010. Organizaçóes \& Sociedade, 20(67), 603-621.

Sullivan, S. E. (1999). The changing nature of careers: A review and research agenda. Journal of Management, 25(3), 457-484.

Sullivan, S. E., \& Arthur, M. B. (2006). The evolution of the boundaryless career concept: Examining physical and psychological mobility. Journal of Vocational Behavior, 69(1), 19-29.

Sullivan, S. E., \& Baruch, Y. (2009). Advances in career theory and research: A critical review and agenda for future exploration. Journal of management, 35(6), 1542-1571.

Sullivan, S. E., \& Mainiero, L. (2008). Using the kaleidoscope career model to understand the changing patterns of women's careers: Designing HRD programs that attract and retain women. Advances in Developing Human Resources, 10(1), 32-49.

Taylor, S., \& Napier, N. K. (2001). An American woman in Turkey: Adventures unexpected and knowledge unplanned 1. Human Resource Management, 40(4), 347-364.

Teixeira, M. L. M., da Paz, M. D. G. T., de Araújo, B. F. V. B., \& Machado, M. M. (2017). Expatriates: The multinationality of multinational and national firms. Organizational Psychology and Evidence-Based Management (pp. 267-285). Springer, Cham.

The Global Gender Gap Report. (2014). World Economic Forum. Retrieved from http://www3. weforum.org/docs/GGGR14/GGGR_CompleteReport_2014.pdf

Tomlinson, J., Baird, M., Berg, P., \& Cooper, R. (2018). Flexible careers across the life course: Advancing theory, research and practice. Human Relations, 71(1), 4-22.

Tung, R. L. (1995). Wanted: a person for all seasons: an examination of managerial skills and core competencies for the twenty-first century. 55th Annual Meetings of the Academy of Management (August 6-9), Vancouver, Canada.

Tung, R. L. (2004). The model global manager? Organizational Dynamics, 33(3), 243-253.

Van Bochove, M., \& Engbersen, G. (2015). Beyond cosmopolitanism and expat bubbles: Challenging dominant representations of knowledge workers and trailing spouses. Population, Space and Place, 21(4), 295-309. 